Since the Mongolian type of imbecility is one that suggests glandular disturbance to many persons, it was thought worth while to make a crude experiment with them. Accordingly, two children were selected during the past year and given the extract, one for a full year, the other for six months. The first was a child, aged 10 years, with a mentality of 4 ; the second, aged 9 years, with a mentality of 3 . For the first montl one capsule a day was given, after that the dose was increased to two capsules a day. The results tend to confirm the previous experiment. Although mental and physical measurements were macle regularly in these cases, there is no evidence of any effect of the gland. Teachers and attendants report the same expierience of "no noticeable improvement."

It is thus seen that the Vineland experience, as far as it goes, is wholly negative.

HENRY H. Golmard, Vincland, N. J.

Director, Department of Research, the Training School.

\section{"THE 'OPEN DOOR' IN CHINA"}

To the Edilor:-Attention having been called to your editorial in the isste of March 31, entitled "The 'Open Door' in China," the Medical Society of South Carolina at its last meting adopted the following resolutions and communicated them to the Department of Commerce:

"That the Medical Society of Sonth Carolinat expresses its surprise at and disapproval of 'Special Consular Report No. 76 ' entitled 'Proprietary Medicine and Ointment Trade in China' published by the Bureat of Forcign and Domestic Commerce of the Department of Commerce"; and

"That this resolution be communicated to the Departnicut of Commerce."

Henry P. Whakner, M.D., Charleston, S. C.

Secretary, Medical Society of Sotth Carolina.

\section{Queries and Minor Notes}

ANONYMOUS Communications and queries on postal cards will not he noticed. Every leller must contain the writer's name and actiress but these will be onitted, on request.

\section{EARIYY WORLERS ON ANTIIRAX}

To the Editor:-Please let me know whether the following men were veterinarians or pluysicians: Chabert, 1780; Barlhelemy, 1823; Ralyer 1)itvaine, 1849; Pollender, 1850; Delafont, 1860; Solleysel, 1664. I hat given the dates approxinately when they wrote. All but Solleysel were concerned in the early work on anthrax; he worked on glanklers. Mazyck P. Ravenel, M.J)., Columbia, Mo.

Answer.-Chalsert, Barthélemy, Delationd and Solleysel were veterinarians.

Dr. Pollender, a physician at Wipperfurth. Rhenish Prussia, wrote the memoir on microscopic and microchemical investigation of the blood in anthrax: "Mikroskopische und Microchemische Untersuchumg des Milzlorandlblutes, sowic iilser Wesen und Kur des Milzbrandes" (Vrlljschr. f. gerichtl, ". üfentl. Mcd., 1855, 8, 103-114).

Casimir-Joseph Davaine, born at St. Amand-les-Eaux in 1811, graduated from the Paris Medical Faculty with the Dissertation "De l'hématocèle de la tunique vaginale" (1837); became a member of the Acadénie de Médecine (1868) and wrote a memoir, crowned by the Institut, entitled "De la paralysie générale ou partielle des deux nerfs de la septieme paire" (1852), but never held a public position. He wrote much on the entozoa, his principal contribution being "Traité des entozoaires et des maladies vermineuses de l'homme et des animaux domestiques" (1860). His greatest contribution is his study of the bacteriology of anthrax: "Recherches sur" la nature et la constitution anatomique de la pustule maligne" (Compt. rend. Acad. d. sc., 1865, 40, 1296-1299). He died at his estate at Garches (Seine-ct-Oise), Oct. 14, 1882.

Biographical references:

Dureau, A.: Bull. sc. dist, d" nord, 1882, 5, 385.393; Gaz. Míd. dc Paris, 1882, Series $6,4,521,533$.

Jahoulbene A.: Compt, end. Sor de biol., 1884, Serics 8, 1, 1.20.

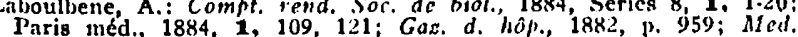
Times and"
Pierre-François-Olive Rayer, born March 8, 1793, at St. Sylvain (Calvados), studied in Paris at the Ecole pratique, Hotel Dieu and Maison royale de Santé, gradnated with the degree of M.D. in 1818, and became a member of the Académie de médecine (1823), and physician to the Bureau central des hôpitaux (1824), Hôpital St. Antoine (1825) and Hôpital de la charité (1832). He succeeded Magendie as president of the Comite consultatif de l'hygiene pulslique (1843), and hecame consulting physician to Lotsis Philippe (1848) and professor of comparative medicine and dean of the Paris Faculty (1862). He died at Paris, Sept. 10, 1867. His greatest works are his treatise on diseases of the kidneys (1839-1841) and the skin (1826) and his classical monograph on glanders and furcy ("De la morve et du farcin chez l'homme," Paris, 1837). He also wrote a history of the epidemic of sweating sickness of 1821 (1822), a memoir on delirium tremens (1819), a report on the origin of the Barcelona epidemic of yellow fever of 1821 (1822), and an investigation of a variety of lematuria endemic in Mauritius (1839). lle became co-editor of the kérue medicale in 1822 and of the Sournal universelle it hebdomaduire de médecine in 18.30 .

References:

Bull. de l'Acad. de mid., 1867, 32, 1107

Gaz. mid. de Paris, 1867, p. 3751.

Jolir. ds colll, mid, prat., 1867, 34, 401.405.

Unim mod., 1867, Series' 3, is, 435; 449.458

\section{TREATALET OF IIORJEOLLM}

To the Editor:-1 wish some information regarding lle most recent and best treatment for lourdeolum or styc. I have a nepliew, aged 5 who has had at least lhinty or forty styes within the past year. have used the various methods of treatment, alteratives, symp of iodid uf irous etc bo you think the canse may be due to some error of refraction?

J. P. Brandon, M.1., Jissex, Mo.

Answik.-Where there have been so many recurrences of styes as in this case, the causative agent is possibly a chronic hlepharitis. This condition, by causing accumulation of scales and crusts on the borders of the lids, favors the multiplication of hacteria that are always present there, and which can thence readily penetrate into the orifices of the glands. The border of the lid may be swollen and this may cause occlusion of the excretory ducts of the glands. If the stye does not yield to abortive treatment (hot applications and antiseptic lotions), it should be incised. Ointment of yellow mercuric oxid is useful in the treatment of blepharitis. General tonic treatment is indicated, especially if the patient is anemic or scrofulous. In this particular case it would probahly he wise to put the eves thoroughly under the influence of a cycloplegic, and determine the alsolute refraction.

\section{FROSTILTA}

7o the Fditor:- Please give me the composition of the "patent med. icine" known as "Prostilla," a lotion for chapped hands. Please ount tatme.

k.

Answer.-.The only reference we find is in "Secret Nostrums and Sy'stems," quoting from the Mruggists Circular:

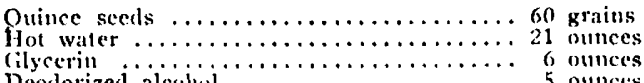

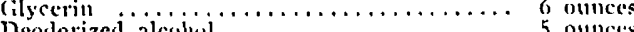

"Place the quince seeds in a bottle, pour the hot water on them and agitate occasionally until a mucilage is formed; then strain through muslin. To this add the glycerin and shake thoroughly. Dissolve the desired perfume in the alcohol and acld the solution to the mucilage and agitate briskly until of a uniform consistency."

\section{VALUTE OF ACTINIC I.IGIIT RAYS IN DFRMIATOLOGY}

To the Editor:-Will you kindly fivor me with your opinion of the therapeutic value of actiuic light rays, particularly in dermatology, as produced by the "Ilereaus ()uartz Liglit" apparatus, made by the lianovia Chemical and Mimufacturing Company, Newark, N. I.? I contemplate purchasing one of these machines, but as they are rather expensive, and the claims of the mantíncturers are rather extravagint, I should like to have a disinterested and competent opinion.

$$
\text { Z. Fut.ter, M.D., Sitc City, Iowa. }
$$

- Answer.-The quartz light apparatus made by the Hanovia Chemical Company is a bona fide ultraviolet ray apparatuse lt has some useful functions in dermatology. It is valuable in a few dermatoses, but, according to experience, its usefulness is limited and a very great deal more restricted than the claims of its makers would indicate. 